\title{
Reactions of vicinal aliphatic bis(hydroxylamines) with trifunctionalized methane derivatives
}

\author{
Evgeny A. Mostovich, ${ }^{\text {a,b }}{ }_{*}$ Dmitrii G. Mazhukin, ${ }^{\text {a,b }}$ and Tatyana V. Rybalova ${ }^{a}$ \\ ${ }^{a}$ N.N. Vorozhtsov Novosibirsk Institute of Organic Chemistry SB RAS, ave. Acad. Lavrent'eva 9, \\ Novosibirsk 630 090, Russia \\ ${ }^{b}$ Novosibirsk State University, Pyrogova, 2, Novosibirsk, 630 090, Russia \\ E-mail: chemmea@gmail.com
}

\begin{abstract}
The reactions of cis-1,2-bis(hydroxylamino)cyclohexane and 2,3-bis(hydroxylamino)-2,3dimethylbutane with polyelectrophilic carbonyl compounds in ethanol were studied. It has been shown that such reactions result in the formation of predominantly five-membered heterocyclic rings with one or two nitrogen atoms. A nitronylnitroxide radical of 2-imidazoline type bearing a 1,3-dicarbonyl function was synthesized.
\end{abstract}

Keywords: 1,2-Bis(hydroxylamines), carbonyl compounds, nitrogen heterocycles, nitronylnitroxides

\section{Introduction}

Aliphatic 1,2-bis(hydroxylamines) (BHAs) were regarded as a suitable precursors in the synthesis of heterocyclic compounds such as 1,2-diazetes ${ }^{1}$, imidazoles ${ }^{2}$, pyrazines ${ }^{3}, 1,4-$ diazepines ${ }^{4}$ bearing $\mathrm{N}$-oxide-, $\mathrm{N}$-hydroxy-, hydroxamic, $\mathrm{N}$-alkoxy- moieties. Many of such compounds possess wide diversity of biological activity. 1,2-Diazete derivatives has been shown as effective NO-donors ${ }^{5}$, 2-imidazolidine carboxylic acids and 2,3-piperazinedione derivatives revealed potent antiaggregatory properties ${ }^{6}$. Furthermore, 1,3-dihydroxyimidazolidines are key intermediates for the synthesis of stable nitronyl- and iminonitroxide radicals which are widely used to design organic and hybrid magnetic materials ${ }^{7}$. On the other hand, the recent observations that $\mathrm{C}_{2}$-symmetric bishydroxamic acids and dinitrones serve as effective ligands and catalysts for enantioselective epoxidation of allylic and homoallylic alcohols ${ }^{8}$, oxidation of sulfides and disulfides ${ }^{9}$ and asymmetric allylation of aldehydes ${ }^{10}$, correspondingly, have drawn special attention to new chiral BHAs ${ }^{11}$. Therefore, systematic study of chemical behavior of these BHAs is of particular interest due to their both theoretical and practical application. This paper is aimed at studying the reactions of BHAs 1a,b with polyelectrophilic carbonyl 
compounds 2a-e, derivatives of trifunctionalized methane. The latter compounds containing aldehyde, ketone, alkoxycarbonyl, nitrile groups, etc. as it was shown by Nishiwaki, Ariga et al. are effective synthetic blocks for the construction of heterocycles with desired functional $\operatorname{group}(\mathrm{s}){ }^{12}$

\section{Results and Discussion}

We have found that the reactions of carbonyl containing compounds with symmetric BHAs 1a,b lead predominantly to the formation of 5-membered rings. Thus the reaction of cis-1,2bis(hydroxylamino)cyclohexane 1a with ethyl ester of ethoxymethylenecyanoacetic acid $\mathbf{2 a}$ in ethanol at room temperature give 1-hydroxyimidazol-2-ylidene 3a (Scheme 1). NMR ${ }^{13} \mathrm{C}$ Spectrum of 3a contains characteristic signals of carbon atoms from exocyclic $\mathrm{C}=\mathrm{C}$ bond at 171.2 and $76.6 \mathrm{ppm}$, whereas the singlets of ester and amide carbon atoms appeared at 168.0 and 167.1 ppm respectively. Spectral characteristics of compound 3a are similar to those for the earlier prepared derivative $\mathbf{3} \mathbf{b}^{13}$.

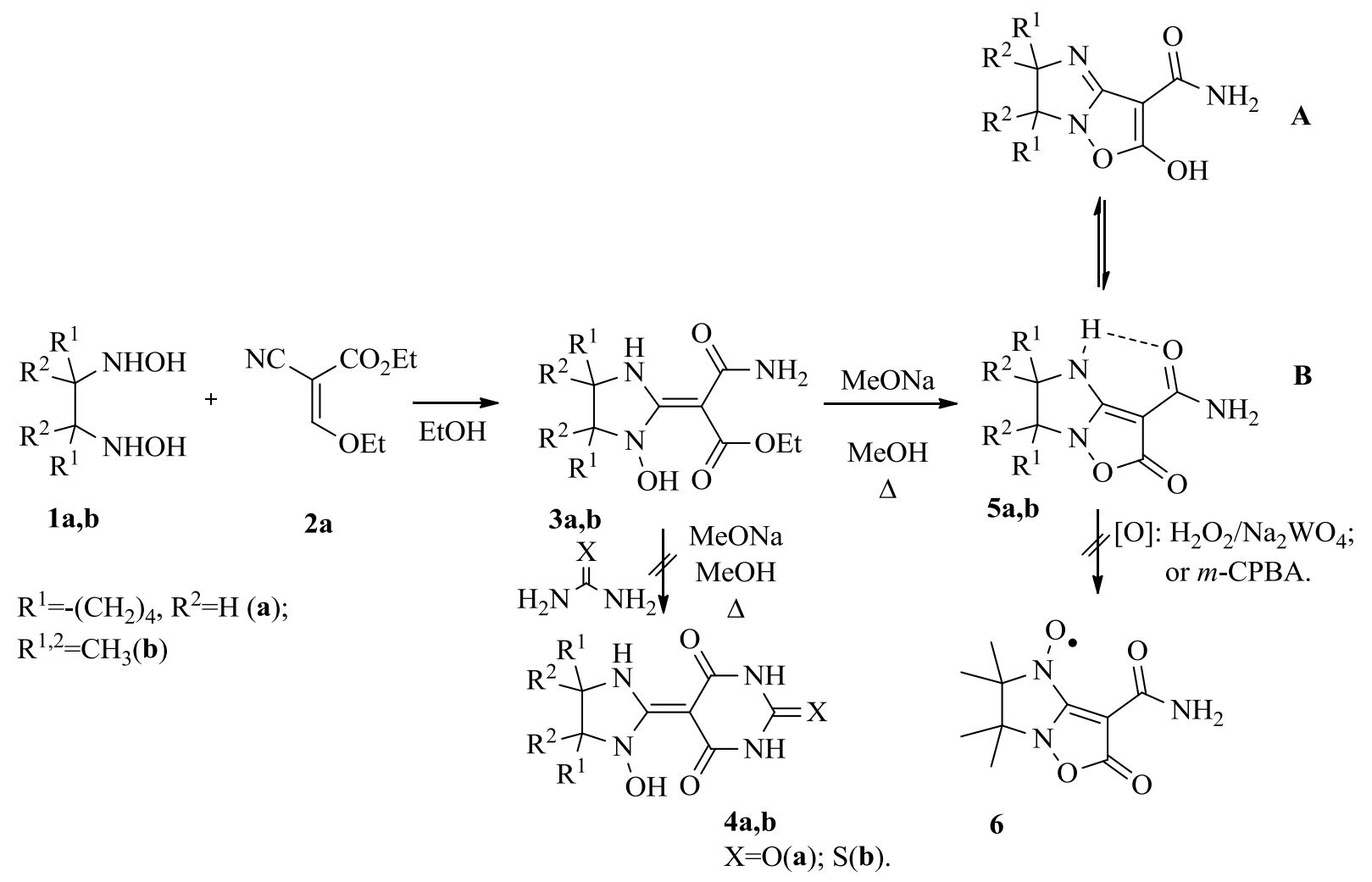

Scheme 1. Reaction of BHA 1a,b with ether $\mathbf{2 a}$ and 3a,b cyclization. 
It seems relevant to note that in the course of reaction nitrile function in 2a undergoes hydrolysis both in case of $\mathbf{1 a}$ with secondary hydroxylamino groups and $\mathbf{1 b}$ with sterically hindered tertiary hydroxylamino groups. ${ }^{13}$

Taking into consideration the synthesis of physiologically active barbituric acid derivatives, compounds 3a,b were treated with carbamide and thiocarbamide. However, the desired pyrimidine derivatives $\mathbf{4 a , b}$ were not observed in this reaction. It was shown that independent refluxing of 3a,b in methanol with MeONa led to imidazo[1,2-b]isoxazoles 5a,b. High downfield shift of NH proton of enamine group in NMR ${ }^{1} \mathrm{H}$ spectrum at $9.43 \div 9.50 \mathrm{ppm}$ can be explained either by the existence of strong intramolecular hydrogen bonding between NH proton and oxygen atom of amide group or fast equilibrium between tautomeric forms $\mathbf{A}$ and $\mathbf{B}$.

An attempt of oxidation of bicycle $\mathbf{5 b}$ in $\mathrm{H}_{2} \mathrm{O}_{2} / \mathrm{Na}_{2} \mathrm{WO}_{4}$ medium has led to $100 \%$ conversion of initial compound, but none of the paramagnetic species such as $\mathbf{6}$ were observed in the reaction mixture.

Reaction of BHA 1a with a masked form of diethyl 2-formylmalonate, compound $\mathbf{2 b}$ in the presence of $\sim 10$ eq $\mathrm{HCl}$ gave a fine crystalline precipitate of product with elemental formula $\mathrm{C}_{12} \mathrm{H}_{21} \mathrm{ClN}_{2} \mathrm{O}_{6}$ in $47 \%$ yield. Spectral data of the compound does not correspond to either neither imidazolidine 7 or diazepine 8 structures. In fact, according to NMR ${ }^{1} \mathrm{H}$ spectrum only one set of protons with relative intensity 5 was observed for the ethyl group, whereas the IR spectrum of this product contains a strong band at $1776 \mathrm{~cm}^{-1}$ which is not typical for carbonyl group in cyclic hydroxamic acids.
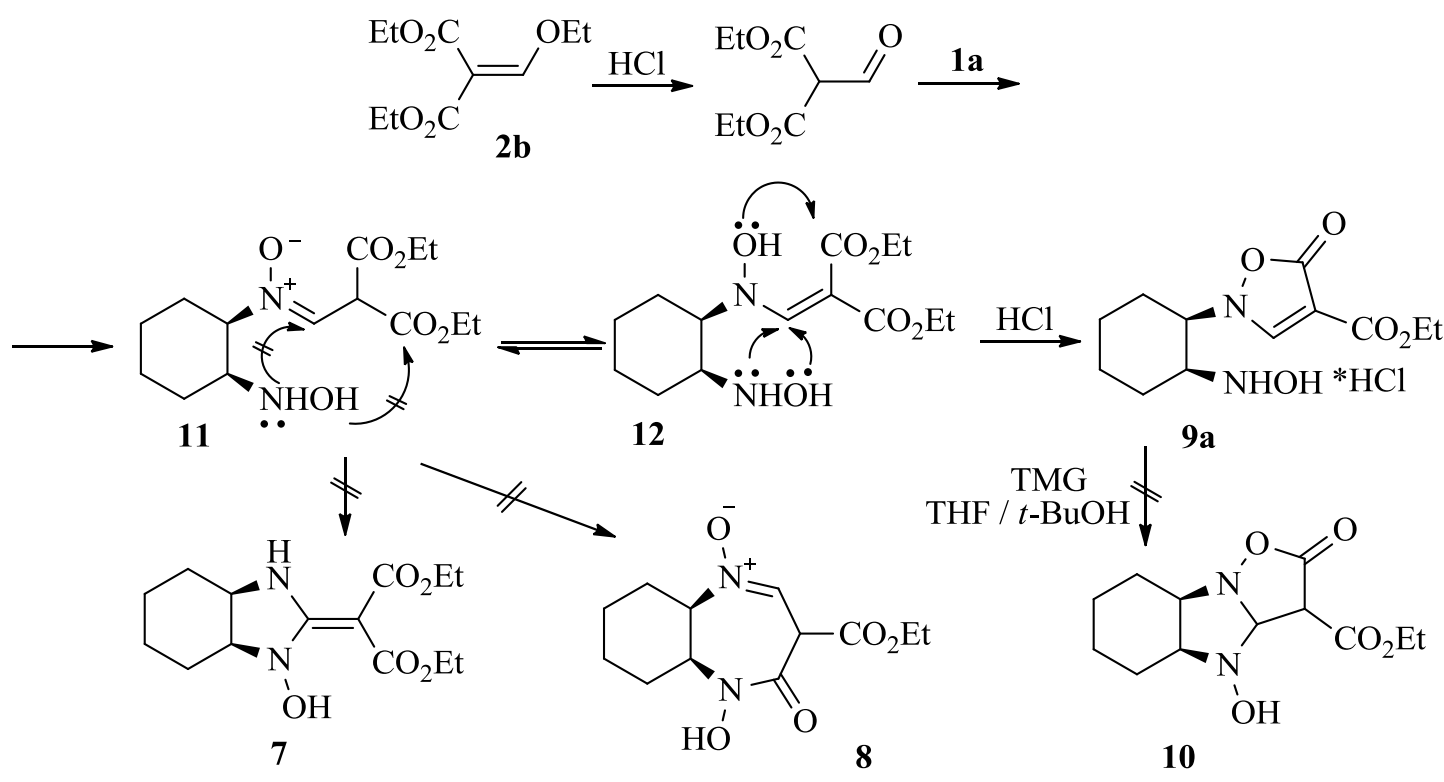

Scheme 2. Reaction of BHA 1a,b with ether $\mathbf{2 b}$ and $9 \mathbf{a}$ synthesis.

The crystals of isolated compound suitable for X-ray analysis were grown by slow vaporization of its ethanol solution and the structure was determined as isoxazolin-5-one 
hydrochloride hydrate 9a. Figure 1 depicts the solid-state molecular structure. Isoxazol cycle is plane within $\pm 0.013(1) \AA$, with bond lengths being close to the corresponding ones in 4-(2methoxybenzyl)-3-phenyl-2H-isoxazol-5-one ${ }^{14}$. The $\mathrm{O} 2, \mathrm{O} 4$ and $\mathrm{C} 10$ atom deviations from isoxazol ring plane equal to $0.065(4), 0.012(4)$ and $0.012(4) \AA$ respectively. Cyclohexyl ring adopts chair conformation. The torsional angle $\mathrm{C} 2 \mathrm{C} 1 \mathrm{~N} 1 \mathrm{O} 1$ characterizing orientation of izoxazol ring to cyclohexyl one is $63.6(3)^{\circ}$. The shortened intramolecular contact $\mathrm{O} 2 \ldots \mathrm{O} 4$ equal to 3.021(2) $\AA$ and weak intramolecular hydrogen bond $\mathrm{C} 3-\mathrm{H} 3 \mathrm{~A} \ldots \mathrm{O} 1$ with parameters: $\mathrm{C}-\mathrm{H}$ 0.96(2), H...O 2.55(2), C...O 3.144(3) A, C-H...O 120(2) were observed. The crystal structure of compound under investigation is characterized by a big number of hydrogen bonds due to water molecules and chlorine anion (Table 1).

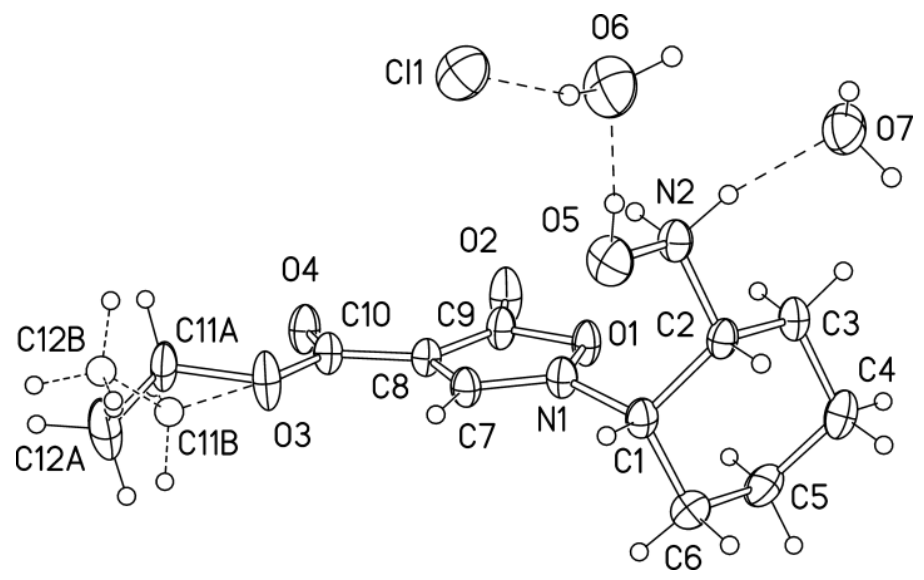

Figure 1. The structure of 2-(2-(Hydroxyamino)cyclohexyl)-5-oxo-2,5-dihydroisoxazole-4carboxylic acid ethyl ester hydrochloride hydrate 9a.

Table 1. Intermolecular hydrogen bonds in crystal of 2-(2-(Hydroxyamino)cyclohexyl)-5-oxo2,5-dihydroisoxazole-4-carboxylic acid ethyl ester hydrocloride 9a

\begin{tabular}{|c|c|c|c|c|}
\hline \multirow{2}{*}{ Bond } & \multicolumn{4}{|c|}{ Parameters of hydrogen bonds } \\
\hline & $\mathrm{D}-\mathrm{H}(\AA)$ & H...A $(\AA)$ & D...A $(\AA)$ & D - H...A $\left(^{\circ}\right)$ \\
\hline $\mathrm{N} 2-\mathrm{H} 2 \ldots \mathrm{O} 7$ & $0.94(2)$ & $1.78(2)$ & $2.693(3)$ & $167(2)$ \\
\hline $\mathrm{N} 2-\mathrm{H} 1 \ldots \mathrm{O} 2$ & $0.92(2)$ & $2.40(2)$ & $2.925(3)$ & $116(2)$ \\
\hline $\mathrm{N} 2-\mathrm{H} 1 \ldots \mathrm{O} 4$ & $0.92(2)$ & $2.02(2)$ & $2.877(2)$ & $153(2)$ \\
\hline $\mathrm{O} 5-\mathrm{H} 1 \ldots \mathrm{O} 6$ & $0.87(2)$ & $1.74(2)$ & $2.598(3)$ & $174(2)$ \\
\hline $\mathrm{O} 6-\mathrm{H} 2 \ldots \mathrm{Cl} 1$ & $0.85(3)$ & $2.33(3)$ & $3.164(3)$ & $167(3)$ \\
\hline O6-H1 ...Cl1 & $0.87(3)$ & $2.39(3)$ & $3.259(3)$ & $176(3)$ \\
\hline $\mathrm{O} 7-\mathrm{H} 2 \ldots \mathrm{Cl1}$ & $0.85(3)$ & $2.27(3)$ & $3.122(2)$ & $178(4)$ \\
\hline $\mathrm{O} 7-\mathrm{H} 1 \ldots \mathrm{Cl1}$ & $0.86(3)$ & $2.31(3)$ & $3.162(2)$ & $177(3)$ \\
\hline
\end{tabular}

Plausible explanation of such unexpected result of this reaction is the initial formation of acylic nitrone $\mathbf{1 1}$ followed by tautomeric shift to hydroxylamine $\mathbf{1 2}$ and final intramolecular ring 
closure (Scheme 2). The formation of hydrochloride salt has obviously stopped any further transformations. We did not succeed in performing intramolecular cyclization of 9a into tricycle $\mathbf{1 0}$ at the presence of tetramethylguanidine (TMG).

Again, the increase of electronegative character of polycarbonyl compound has led to the unusual result in the reaction with BHAs. When 3-ethoxymethylene-2,4-pentanedione 2c was involved in condensations with BHAs 1a,b neither the expected cyclic ketenaminals 13a,b nor isoxazoline derivatives 14a,b were obtained. The synthesized substances proved to be identical with the products prepared earlier in the reaction of acetoacetaldehyde diethylacetal with BHA $\mathbf{1 a}, \mathbf{b}$ in acidic medium ${ }^{13}$, i.e. acetylimidazolidine-2-ylidenes 15a,b (Scheme 3). When optimizing this reaction, we found that heating of the components in the mixture of $\mathrm{HCl}$ and EtOH affords 15a quantitatively. Thus, ketenaminal 15a was isolated with $95 \%$ yield applying the above mentioned conditions, while running this reaction in neutral medium led to a dramatic drop in yield of 15a down to $41 \%$, which is supposed to make $\mathbf{2 c}$ a useful alternative of 4,4diethoxybutan-2-one for efficient preparation of acetylated imidazolidin-2-ylidenes.

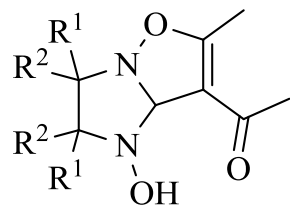

14a,b

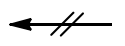

$\mathrm{R}^{1}=-\left(\mathrm{CH}_{2}\right)_{4}, \mathrm{R}^{2}=\mathrm{H}(\mathbf{a})$;

$\mathrm{R}^{1,2}=\mathrm{CH}_{3}(\mathbf{b})$

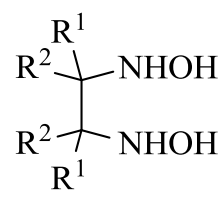

1a,b

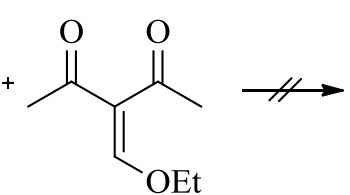

2c

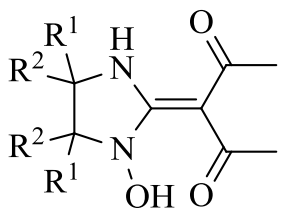

13a,b

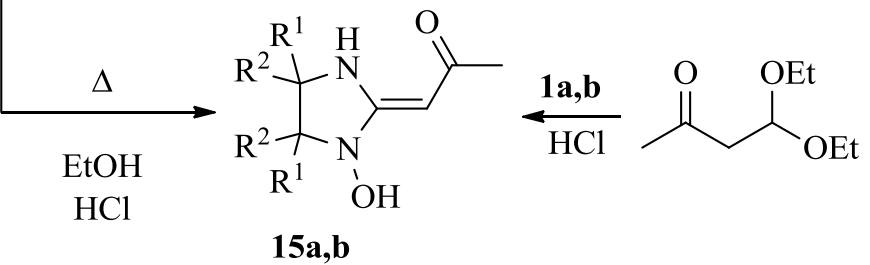

Scheme 3. Reaction of BHA 1a,b with ether 2c.

The similar deacylation reactions with ketene aminals were described earlier in literature. Thus, Huang et al. has observed monodeacetylation process for diacetylmethylene derivatives of imidazolidine, oxazolidine, hexahydropyrimidine by treatment of the listed heterocycles with alkali $^{15}$. At the same time, the related process was registered when dibenzoylmethyleneimidazolidine was subject to hydrolysis furnished to monobenzoylated $\operatorname{product}^{16}$.

Reaction of BHA 1a with 2-ethoxymethylene derivative of ethyl acetoacetate $\mathbf{2 d}$ in ethanol at room temperature led to the precipitation of white solid. IR-spectrum of a product reveals an intensive absorption at $1716 \mathrm{~cm}^{-1}$ that is specific for ester's group valent vibrations. The analysis of NMR spectra of an isolated compound reveals that this product consists of the mixture of 
diastereomers of imidazo[1,2-b]isoxazole 16a. Likewise, BHA 1b reacted with 2d, giving isoxazole 16b (Scheme 4).

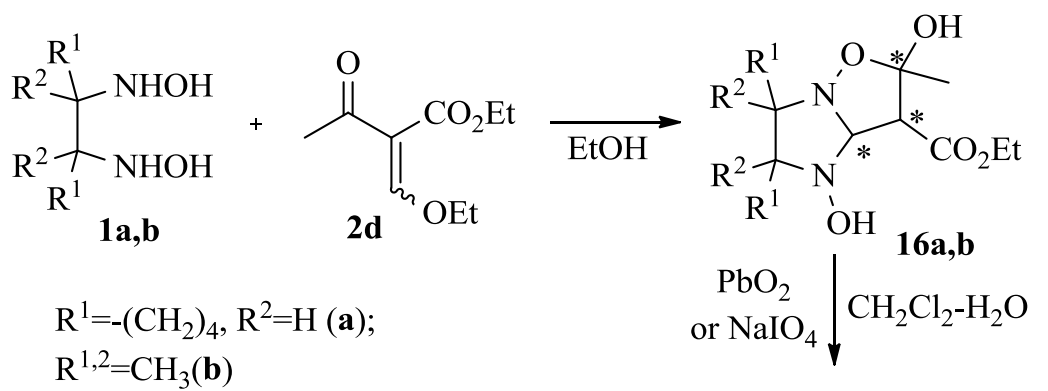

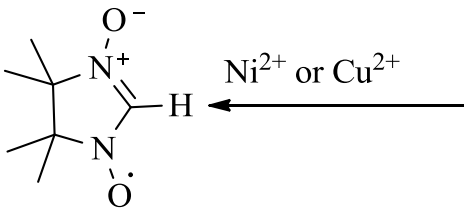

17

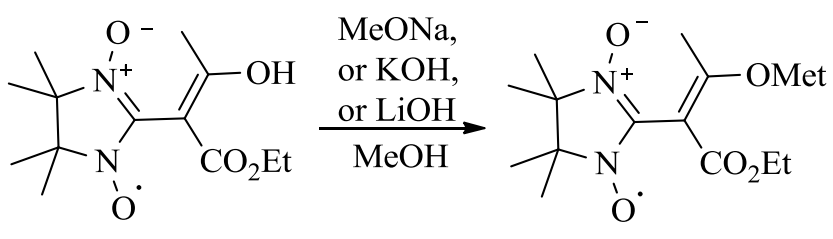

18
19Met

$\mathrm{Met}=\mathrm{Li}, \mathrm{Na}, \mathrm{K}$

Scheme 4. Synthesis of imidazo[1,2-b]isoxazoles 16a,b and nitronyl nitroxides 18-19Met.

Besides, the synthesis of nitronyl nitroxides (NNR) possessing 1,3-dicarbonyl functionality oxidation of $\mathbf{1 6} \mathbf{b}$ was studied. When treating the solution of imidazo[1,2-b]isoxazole $\mathbf{1 6}$ with an excess of $\mathrm{PbO}_{2}$ (or aqueous $\mathrm{NaIO}_{4}$ ) in a few minutes, there is a deep coloration of organic phase in the red-purple color due to the formation of radical 18. Despite the fact that only a single product was formed in this reaction (as monitored by TLC), obtaining NNR $\mathbf{1 8}$ in its pure form seems to be quite problematic since it is a strong $\mathrm{CH}$-acid which is very labile. In particular, the color of the mixture changed from dark purple to a dirty-yellow upon standing of NNR solution at room temperature for $12 \mathrm{~h}$. To obtain nitronyl nitroxide in a persistent form of freshly prepared solution of $\mathbf{1 8}$ was treated with alkali solutions ( $\mathrm{MeONa}, \mathrm{LiOH}$ and $\mathrm{KOH}$ were used) in $\mathrm{MeOH}$. As a result, a deep violet sodium salt $19 \mathrm{Na}$ as well as other salts were isolated and characterized by IR, UV and ESR-spectroscopy. To illustrate, UV-spectrum of 19Na is represented by two absorption maxima at 314 and $573 \mathrm{~nm}$ (characteristic for $\pi \rightarrow \pi^{*}$ and $\mathrm{n} \rightarrow \pi^{*}$ transitions). In ESR spectrum there is a characteristic quintet with relative intensities as 1:4:6:4:1 and with hyperfine coupling constant for two equivalent imidazoline nitrogen nuclei $a_{\mathrm{N} 1}=a_{\mathrm{N} 2}=0.750 \mathrm{mT}, \mathrm{g}_{\mathrm{iso}}=2.0065$, which is typical of nitronylnitroxides (Figure 2).

Crystallization of NNR 18 with the salt of nickel has led to an unexpected formation of red paramagnetic crystals, which, as it turned out, are known as NNR $17^{17}$, unsubstituted at the 2position of the heterocycle. The same results were obtained when $\mathrm{Cu}(\mathrm{OAc})_{2}$ was used. Complexation of radical salt $\mathbf{1 9 N a}$ with $\mathrm{Mn}(\mathrm{hfac})_{2}$ or $\mathrm{Cu}(\mathrm{hfac})_{2}$ has led to noncrystalline material with nonconstant chemical composition. 


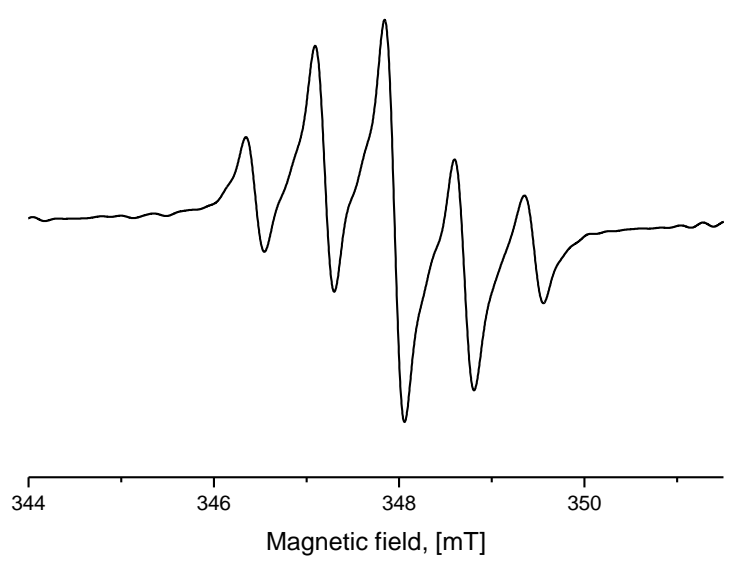

Figure 2. ESR spectra of $19 \mathrm{Na}\left(\mathrm{c}=10^{-6} \mathrm{M}, \mathrm{CHCl}_{3}\right)$.

In order to study the elimination of acyl fragment in the reaction of BHAs with polycarbonyl compounds we synthesized cyclic 1,3-ketoaldehyde - 2-formyl-3-ketosulpholane $\mathbf{2 e}$ by acylation of useful synthetic block, 3 -sulpholanone $\mathbf{2 0}^{19}$ according to Claisen procedure ${ }^{18}$. We assumed that the structural rigidity of molecule $2 \mathbf{e}$ will prevent the rupture of the $\mathrm{C}-\mathrm{C}$ bond in the reagent, so that the reaction product will be imidazolidinylidene with two electron-withdrawing substituents at the terminal atom of enamine fragment.

However, the reaction of 1,3-ketoaldehyde $\mathbf{2} \mathbf{e}$ with BHA $\mathbf{1 a}$ in acid containing media has led to the compound with molecular formula $\mathrm{C}_{16} \mathrm{H}_{22} \mathrm{~N}_{2} \mathrm{O}_{8} \mathrm{~S}_{2}$, which corresponds to the adduct of one molecule of 1,2-bishydroxylamine with two molecules of ketosulpholane. Indeed, the set of spectral data allowed us to assign the structure of a symmetric dinitrone $\mathbf{2 2}$ for separated compound.

According to NMR spectra, dinitrone 22 exists in DMSO solution in a conjugated tautomeric form $22 \mathrm{C}$ rather than in the enamine form $22 \mathrm{~B}$ or alternative form of ketonitrone $22 \mathrm{~A}$. In NMR ${ }^{1} \mathrm{H}$ spectrum of 22, the singlet signal from aldonitrone proton appears at $7.79 \mathrm{ppm}$ while the corresponding signal from carbon atom in NMR ${ }^{13} \mathrm{C}$ spectra has a chemical shift of $138.2 \mathrm{ppm}$ that agrees with the spectra of conjugated nitrones. Also, the signals from carbon atoms of cyclohexane $\mathrm{CH}$-groups appear at $66.3 \mathrm{ppm}$ which points at their coupling to $s p^{2}$-nitrogen atom. The formation of dinitrone in this reaction is likely to occur due to the preferential attack of the second molecule of carbonyl compound by hydroxylamino group in acyclic tautomeric form $\mathbf{2 1}$. 
<smiles>O=C1CCS(=O)(=O)C1</smiles>

20

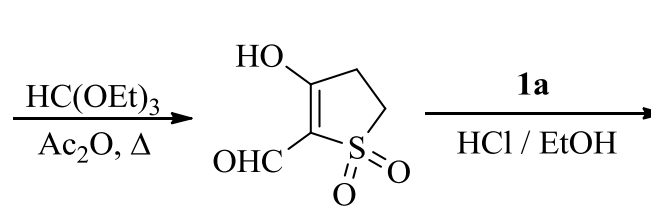

2e

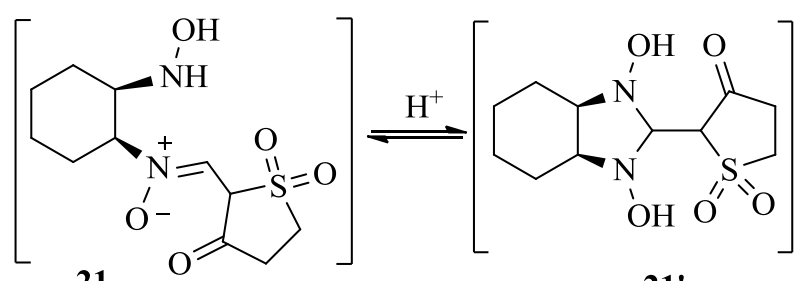

21
21'

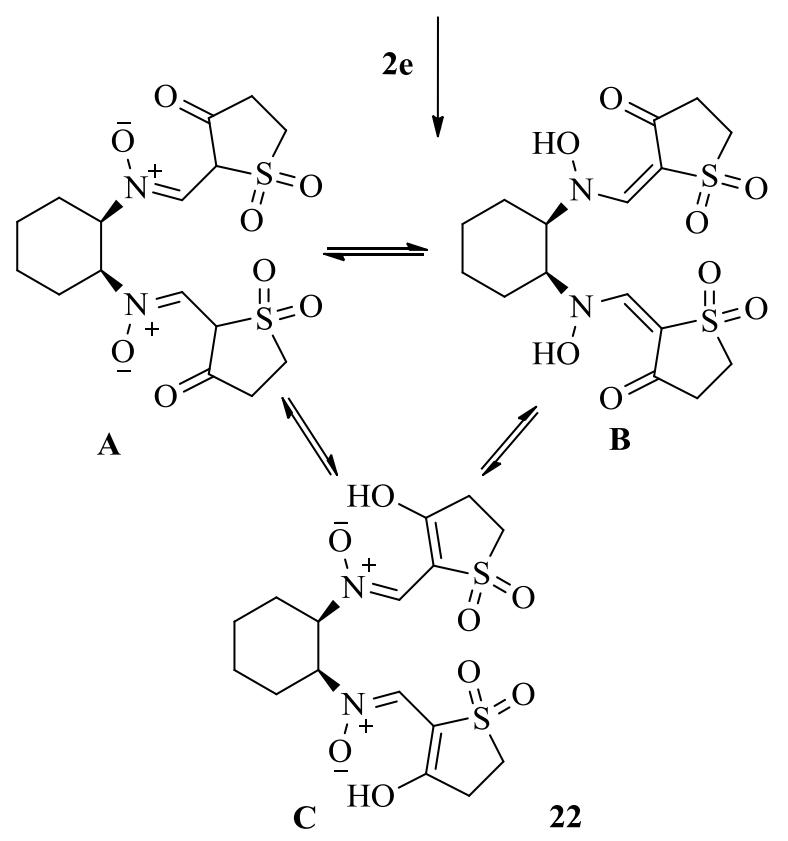

\section{Scheme 5}

\section{Conclusions}

Thus, we have investigated the reactivity of two different aliphatic symmetric BHAs with respect to various acyclic polycarbonyls containing electrophilic moieties, with5-membered heterocyclic rings being the dominant products in these reactions. For the first time, we have synthesized nitronyl nitroxide radical bearing 1,3-dicarbonyl function and studied some of its complexationabilities. The reaction of BHA with cyclic 2-formyl-3-ketosulpholane leads to the formation of open-chain dinitrone.

\section{Experimental Section}

General. BHAs - cis-1,2-bis(hydroxylamino)cyclohexane ${ }^{20} \mathbf{1 a}$ and 2,3-bis(hydroxyamino)-2,3dimethylbutane $^{21} \mathbf{1 b}$ were synthesized as described in literature. Polycarbonyl compounds $\mathbf{2 c}$ and 2d were prepared by formylation of acetylacetone ${ }^{22 a}$ and ethyl acetoacetate ${ }^{22 b}$. Other reagents 
and solvents from commercial sources were of the highest purity available and were used as received. Silufol UV 254 and Merck Kieselgel $60 \mathrm{~F}_{254}$ plates were used for TLC monitoring. Chromatography was carried out with the use of "Merck" silica gel $(0.063-0.100 \mathrm{~mm})$ for column chromatography. C, H, N, Cl and S elemental analyses were carried out by the Chemical Service Center of the Novosibirsk Institute of Organic Chemistry. The melting points were determined on a Boethius type apparatus and not corrected.

IR spectra were recorded on Bruker IFS-66 in $\mathrm{KBr}$ pellets (conc. $0.25 \%, \mathrm{~d}=1 \mathrm{~mm}$ ). UV spectra were registered on Specord M-40. NMR ${ }^{1} \mathrm{H}$ and ${ }^{13} \mathrm{C}$ spectra were obtained on Bruker AC-200, AV-300 and AM-400. X-Band CW ESR spectra were recorded in dilute degassed $\mathrm{CHCl}_{3}$ solutions at room temperature on a Bruker EMX spectrometer.

\section{(E)-3-Amino-2-(1-hydroxy-1H-benzo[d]imidazol-2(3H,3a $H, 4 H, 5 H, 6 H, 7 H, 7 a H)$-ylidene)-3-} oxopropanoic acid ethyl ester (3a). To a stirred suspension of $1 \mathbf{a}(0.50 \mathrm{~g}, 3.4 \mathrm{mmol})$ in ethanol $(5 \mathrm{ml})$ a 2-ethoxymethylenecyanoacetic acid ethyl ester $\mathbf{2 a}(0.57 \mathrm{~g}, 3.4 \mathrm{mmol})$ was added. Light yellow solution was kept $24 \mathrm{~h}$ at room temperature and concentrated in vacuo. Oily residue was chromatographed on a short column with $\mathrm{SiO}_{2}$ using a $\mathrm{CHCl}_{3}$ as eluent. The fractions containing 3a were concentrated under reduced pressure. Viscous oil, yield $92 \%, 0.87 \mathrm{~g}, R_{\mathrm{f}} 0.50\left(\mathrm{CHCl}_{3}-\right.$ methanol 40:1); IR $\left(v_{\max }, \mathrm{cm}^{-1}\right): 3327(\mathrm{NH} / \mathrm{OH}), 1607$ and 1550-1420 $(\mathrm{N}-\mathrm{C}=\mathrm{C}-\mathrm{C}=\mathrm{O}) .{ }^{1} \mathrm{H}$ NMR $\left(200.13 \mathrm{MHz}, \mathrm{CDCl}_{3}\right): \delta 1.29\left(\mathrm{t}, J=7.2 \mathrm{~Hz}, 3 \mathrm{H}, \mathrm{OCH}_{2} \mathrm{CH}_{3}\right), 1.38-2.18\left(3 \mathrm{~m}, 8 \mathrm{H},\left(\mathrm{CH}_{2}\right)_{4}\right), 3.78$ $\left(\mathrm{m}, 2 \mathrm{H},(\mathrm{CH})_{2}\right), 4.22$ (q, J = 7.2 Hz, $2 \mathrm{H}, \mathrm{OCH}_{2} \mathrm{CH}_{3}$ ), 5.40 (br s, 1H, NH), 7.87 (br s, $1 \mathrm{H}, \mathrm{NH}_{2}$ ), 8.12 (br s, $1 \mathrm{H}, \mathrm{NH}_{2}$ ), 11.6 (br s, $\left.1 \mathrm{H}, \mathrm{NOH}\right) .{ }^{13} \mathrm{C} \mathrm{NMR}\left(60.13 \mathrm{MHz}, \mathrm{CDCl}_{3}\right): \delta 14.3\left(\mathrm{OCH}_{2} \mathrm{CH}_{3}\right)$, 19.9, 21.6, 23.6, $31.3\left(\mathrm{CH}_{2}\right.$ cyclohexane), 52.0, $61.4\left(\mathrm{CH}\right.$ cyclohexane), $59.8\left(\mathrm{OCH}_{2} \mathrm{CH}_{3}\right), 76.6$ $\left(=C-\mathrm{CONH}_{2}\left(\mathrm{CO}_{2} \mathrm{Et}\right)\right), 167.1(\mathrm{C}=\mathrm{O}), 168.0(\mathrm{C}=\mathrm{O}), 171.2((\mathrm{NOH}) \mathrm{NH}-C=)$. Anal. Calcd for $\mathrm{C}_{12} \mathrm{H}_{19} \mathrm{~N}_{3} \mathrm{O}_{4}$ (269.30): C, 53.52; H, 7.11; N, 15.60\%. Found: C, 53.57; H, 7.05; N, $15.56 \%$.

(E)-3-Amino-2-(1-hydroxy-4,4,5,5-tetramethylimidazol-2-ylidene)-3-oxopropanoic acid ethyl ester (3b) ${ }^{13}$ was obtained by the procedure described for 3a from $\mathbf{1 b}$ (1.50 g, $\left.10 \mathrm{mmol}\right)$ and 2-ethoxymethylenecyanoacetic acid ethyl ester (1.70 g, $10 \mathrm{mmol})$. Light yellow crystals, yield $73 \%, 1.97 \mathrm{~g}, R_{\mathrm{f}} 0.30\left(\mathrm{CHCl}_{3}\right) ; \mathrm{mp} 118-120{ }^{\circ} \mathrm{C}$; IR( $\left(v_{\max }, \mathrm{cm}^{-1}\right): 3378-3300(\mathrm{NH} / \mathrm{OH}), 1618$ and $1528(\mathrm{~N}-\mathrm{C}=\mathrm{C}-\mathrm{C}=\mathrm{O}) .{ }^{1} \mathrm{H}$ NMR $\left(200.13 \mathrm{MHz}, \mathrm{CDCl}_{3}\right): \delta 1.22\left(\mathrm{~s}, 12 \mathrm{H}, \mathrm{CH}_{3}\right), 1.27(\mathrm{t}, J=6.97 \mathrm{~Hz}$, $3 \mathrm{H}, \mathrm{OCH}_{2} \mathrm{CH}_{3}$ ), 4.17 (q, $J=6.97 \mathrm{~Hz}, 2 \mathrm{H}, \mathrm{OCH}_{2} \mathrm{CH}_{3}$ ), 5.27 (br s, $1 \mathrm{H}, \mathrm{NH}$ ), 7.09 (br s, $1 \mathrm{H}, \mathrm{NH}_{2}$ ), 8.21 (br s, $1 \mathrm{H}, \mathrm{NH}_{2}$ ), 12.5 (br s, $1 \mathrm{H}, \mathrm{N}-\mathrm{OH}$ ).

2-Oxo-2,4,4a,5,6,7,8,8a-octahydrobenzo $[d]$ isoxazolo[2,3-a]imidazole-3-carboxamide (5a). Compound 3a $(1.11 \mathrm{~g}, 3.9 \mathrm{mmol})$ was refluxed in $\mathrm{MeOH}(20 \mathrm{ml})$ and $\mathrm{MeONa}(2 \mathrm{ml}, 4.95 \mathrm{M}$ $\mathrm{MeOH}$ solution) mixture for $3 \mathrm{~h}$. Solvent was removed under reduced pressure, $\mathrm{H}_{2} \mathrm{O}(20 \mathrm{ml})$ and $\mathrm{AcOH}$ were added till $\mathrm{pH}=7$ and extracted by $\mathrm{CHCl}_{3}(3 \times 20 \mathrm{ml})$. Combined organic phases dried under $\mathrm{MgSO}_{4}$, filtered off and solvent was removed under reduced pressure. The so obtained residue was recrystallized from $i$-PrOH. Pale crystals, yield $88 \%, 0.82 \mathrm{~g}, R_{\mathrm{f}} 0.20$ $\left(\mathrm{CHCl}_{3}\right.$ - methanol 40:1); mp 199-201 ${ }^{\circ} \mathrm{C}$; IR $\left(v_{\max }, \mathrm{cm}^{-1}\right): 3190(\mathrm{NH}), 2940\left(\mathrm{CH}_{3}\right), 1735,1657$ and $1582(\mathrm{~N}-\mathrm{C}=\mathrm{C}-\mathrm{C}=\mathrm{O}) .{ }^{1} \mathrm{H}$ NMR $\left(300.13 \mathrm{MHz},\left(\mathrm{CD}_{3}\right)_{2} \mathrm{SO}\right): \delta 1.10-1.90\left(\mathrm{~m}, 8 \mathrm{H},\left(\mathrm{CH}_{2}\right)_{4}\right), 3.90-$ $4.10\left(\mathrm{~m}, 2 \mathrm{H},(\mathrm{CH})_{2}\right), 6.68$ (br s, $\left.1 \mathrm{H}, \mathrm{NH}_{2}\right), 7.07$ (br s, $\left.1 \mathrm{H}, \mathrm{NH}_{2}\right), 9.43$ (br s, $1 \mathrm{H}, \mathrm{NH}$ or $\left.\mathrm{OH}\right) .{ }^{13} \mathrm{C}$ 
NMR (75.47 MHz, $\left.\left(\mathrm{CD}_{3}\right)_{2} \mathrm{SO}\right): \delta$ 20.9, 21.4, 23.0 (4C, $\mathrm{CH}_{2}$ cyclohexane), 57.0, 64.3 (2C, $\mathrm{CH}$ cyclohexane), $78.3\left(=C-\mathrm{CONH}_{2}\right), 164.0(\mathrm{C}=\mathrm{O}), 172.1((\mathrm{~N}) \mathrm{NH}-C=), 172.3(\mathrm{C}=\mathrm{O})$. Anal. Calcd for $\mathrm{C}_{10} \mathrm{H}_{13} \mathrm{~N}_{3} \mathrm{O}_{3}$ (223.23): C, 53.80; H, 5.87; N, 18.82. Found: C, 53.96; H, 5.82; N, 18.63;

2,2,3,3-Tetramethyl-6-oxo-1,2,3,6-tetrahydroimidazo[1,2-b]isoxazole-7-carboxamide was obtained by the procedure described for $\mathbf{5 a}$ from $\mathbf{3 b}(0.27 \mathrm{~g}, 1 \mathrm{mmol})$. Pale crystals, yield $70 \%, 0.18 \mathrm{~g}, R_{\mathrm{f}} 0.15\left(\mathrm{CHCl}_{3}\right.$ - methanol 40:1); dec $>180{ }^{\circ} \mathrm{C} ; \mathrm{IR}\left(v_{\max }, \mathrm{cm}^{-1}\right): 3417(\mathrm{NH}), 2972$ $\left(\mathrm{CH}_{3}\right), 1724,1667,1600$ and $1542(\mathrm{~N}-\mathrm{C}=\mathrm{C}-\mathrm{C}=\mathrm{O}) .{ }^{1} \mathrm{H}$ NMR $\left(300.13 \mathrm{MHz},\left(\mathrm{CD}_{3}\right)_{2} \mathrm{SO}\right): \delta 1.13-$ 1.20 (s, 6H, $\mathrm{CH}_{3}$ ), 1.29-1.34 (s, 6H, $\mathrm{CH}_{3}$ ), 6.82 (br s, $1 \mathrm{H}, \mathrm{NH}_{2}$ ), 7.47 (br s, $1 \mathrm{H}, \mathrm{NH}_{2}$ ), 9.50 (br s, $1 \mathrm{H}, \mathrm{NH}$ or $\mathrm{OH}) .{ }^{13} \mathrm{C} \mathrm{NMR}\left(75.47 \mathrm{MHz},\left(\mathrm{CD}_{3}\right)_{2} \mathrm{SO}\right): \delta 17.6,22.7\left(4 \mathrm{C}, \mathrm{CH}_{3}\right), 59.0,67.3(2 \mathrm{C}$, $\left.\mathrm{C}\left(\mathrm{CH}_{3}\right)_{2}\right), 77.7\left(=C-\mathrm{CONH}_{2}\right), 163.5(\mathrm{C}=\mathrm{O}), 171.6((\mathrm{~N}) \mathrm{NH}-\mathrm{C}=), 171.8(\mathrm{C}=\mathrm{O})$. Anal. Calcd for $\mathrm{C}_{10} \mathrm{H}_{15} \mathrm{~N}_{3} \mathrm{O}_{3}$ (225.24): C, 53.32; H, 6.71; N, 18.66\%. Found: C, 52.66; H, 6.57; N, $18.30 \%$.

2-(2-(Hydroxyamino)cyclohexyl)-5-oxo-2,5-dihydroisoxazole-4-carboxylic acid ethyl ester hydrocloride (9a). To solution of $\mathbf{1 a}(1.46 \mathrm{~g}, 10 \mathrm{mmol})$ in $\mathrm{EtOH}(8 \mathrm{ml}) \mathrm{HCl}_{\text {(conc.) }}(1.3 \mathrm{ml})$ was added till $\mathrm{pH}=3-4$, then solution of 2-methylendioxydiethylmalonate $\mathbf{2 b}(2.59 \mathrm{~g} ; 12 \mathrm{mmol})$ in $\mathrm{EtOH}(2 \mathrm{ml})$ was added and obtained mixture was left for $72 \mathrm{~h}$ at room temperature. The so obtained residue was filtered off, washed with $\mathrm{EtOH}(5 \mathrm{ml})$ and dried on air. Colorless crystals, yield 39\%, $1.26 \mathrm{~g}, R_{\mathrm{f}} 0.20\left(\mathrm{CHCl}_{3}-\right.$ methanol 40:1); mp 135-137 ${ }^{\circ} \mathrm{C}$; IR( $\left(v_{\max }, \mathrm{cm}^{-1}\right): 3470(\mathrm{OH})$, 1776, 1695 and $1566(\mathrm{C}=\mathrm{C}-\mathrm{C}=\mathrm{O}) .{ }^{1} \mathrm{H}$ NMR $\left(200.13 \mathrm{MHz},\left(\mathrm{CD}_{3}\right)_{2} \mathrm{SO}\right): \delta 1.18(\mathrm{t}, J=7.2 \mathrm{~Hz}, 3 \mathrm{H}$, $\left.\mathrm{OCH}_{2} \mathrm{CH}_{3}\right), 1.40-2.83\left(\mathrm{~m}, 8 \mathrm{H},\left(\mathrm{CH}_{2}\right)_{4}\right), 3.33$ and $4.41\left(\mathrm{~m}, 2 \mathrm{H},(\mathrm{CH})_{2}\right), 4.19(\mathrm{q}, J=7.2 \mathrm{~Hz}, 2 \mathrm{H}$, $\mathrm{OCH}_{2} \mathrm{CH}_{3}$ ); 4.70-6.70 (br s, $\left.2 \mathrm{H}, \mathrm{NHOH}\right), 8.97(\mathrm{~s}, 1 \mathrm{H}, \mathrm{NCH}=\mathrm{C}) .{ }^{13} \mathrm{C} \mathrm{NMR}(200.13 \mathrm{MHz}$ $\left.\left(\mathrm{CD}_{3}\right)_{2} \mathrm{SO}\right): \delta 13.3\left(\mathrm{OCH}_{2} \mathrm{CH}_{3}\right), 20.9,25.1\left(4 \mathrm{C}, \mathrm{CH}_{2}\right.$, cyclohexane), 47.7, (C, $\mathrm{CH}$, cyclohexane), 58.4 $\left(\mathrm{OCH}_{2} \mathrm{CH}_{3}\right)$, 60.1(C, $\mathrm{CH}$, cyclohexane), 87.4 (=C), $150.3(\mathrm{NCH}=), 160.1,163.9(\mathrm{C}=\mathrm{O})$. Anal. Calcd for $\mathrm{C}_{12} \mathrm{H}_{18} \mathrm{~N}_{2} \mathrm{O}_{5} \cdot \mathrm{HCl} \cdot \mathrm{H}_{2} \mathrm{O}$ (324.76): $\mathrm{C} 44.38, \mathrm{H}$ 6.52, $\mathrm{Cl} 10.92, \mathrm{~N}$ 8.63\%. Found: $\mathrm{C}$ 44.62, H 6.35, $\mathrm{Cl} 10.82, \mathrm{~N} 8.64 \%$.

\section{1-(1-Hydroxy-1H-benzo[d]imidazole-2(3H,3a $H, 4 H, 5 H, 6 H, 7 H, 7 \mathrm{a} H)$-ylidene)propane-2-one}

(15a). ${ }^{13}$ Solution of $\mathbf{1 a}(146 \mathrm{mg}, 1 \mathrm{mmol})$, 3-ethoxymethylene-2,4-pentanedione $\mathbf{2 c}$ (156 $\mathrm{mg}$, $1 \mathrm{mmol})$ and $\mathrm{HCl}_{\text {(conc.) }}(0.3 \mathrm{ml})$ in $\mathrm{EtOH}(5 \mathrm{ml})$ was refluxed for $12 \mathrm{~h}$. Solvent was removed under reduced pressure, the so obtained residue was diluted with $\mathrm{Et}_{2} \mathrm{O}(10 \mathrm{ml})$ and kept at $-12^{\circ} \mathrm{C}$ for 24 h. Pale crystals were filtered off, dissolved in minimum $\mathrm{CHCl}_{3}$ and chromatographed by TLC on $\mathrm{SiO}_{2}$ using mixture of $\mathrm{CHCl}_{3}-\mathrm{MeOH}(20: 1)$ as eluent. Pale crystals, yield $91 \%, 180 \mathrm{mg}, R_{\mathrm{f}} 0.30$ $\left(\mathrm{CHCl}_{3}-\mathrm{MeOH}, 20: 1\right)$, mp 182-185 ${ }^{\circ} \mathrm{C}$ (lit. $\left.{ }^{13} 185{ }^{\circ} \mathrm{C}\right) . \operatorname{IR}\left(v_{\max }, \mathrm{cm}^{-1}\right): 3327(\mathrm{NH} / \mathrm{OH}), 1607$, 1550-1420 (N-C=C-C=O). ${ }^{1} \mathrm{H}$ NMR (400.13 MHz, $\left.\left(\mathrm{CD}_{3}\right)_{2} \mathrm{SO}\right): \delta 1.12-1.83\left(\mathrm{~m}, 8 \mathrm{H},\left(\mathrm{CH}_{2}\right)_{4}\right)$, $1.85\left(\mathrm{~s}, 3 \mathrm{H}, \mathrm{COCH}_{3}\right), 3.37$ and $3.59\left(\mathrm{~m}, 2 \mathrm{H},(\mathrm{CH})_{2}\right), 4.85(\mathrm{~s}, 1 \mathrm{H}, \mathrm{C}=\mathrm{CH}), 8.73$ and 9.30 (br s, $1 \mathrm{H}, \quad \mathrm{NH} / \mathrm{OH}) .{ }^{13} \mathrm{C} \mathrm{NMR}\left(100.13 \mathrm{MHz}\left(\mathrm{CD}_{3}\right)_{2} \mathrm{SO}\right): \delta 20.2,21.4,23.5,28.8\left(4 \mathrm{C}, \mathrm{CH}_{2}\right.$ cyclohexane), $28.9\left(\mathrm{COCH}_{3}\right), 51.3,61.5(2 \mathrm{C}, \mathrm{CH}$ cyclohexane $), 78.6(=\mathrm{CH}), 165.3(\mathrm{C}=\mathrm{O}), 190.6$ $(\mathrm{C}=)$.

1-(1-Hydroxy-4,4,5,5-tetramethylimidazolidine-2-ylidene)propan-2-one $(15 b){ }^{13}$ was obtained by the procedure described for $\mathbf{1 5 a}$ from $\mathbf{1 b}(146 \mathrm{mg}, 1 \mathrm{mmol})$ and $\mathbf{2 c}(150 \mathrm{mg}, 1 \mathrm{mmol})$. Pale crystals, yield $25 \%, 50 \mathrm{mg}, R_{\mathrm{f}} 0.40\left(\mathrm{CHCl}_{3}\right.$ - methanol 20:1); mp 143-146 ${ }^{\circ} \mathrm{C}$ (lit. $\left.{ }^{13} 142{ }^{\circ} \mathrm{C}\right)$. $\operatorname{IR}\left(v_{\max }, \mathrm{cm}^{-1}\right): 3324(\mathrm{NH} / \mathrm{OH}), 1608,1540-1420(\mathrm{~N}-\mathrm{C}=\mathrm{C}-\mathrm{C}=\mathrm{O})$. 
2,4-Dihydroxy-2-methyldecahydrobenzo[ $d]$ isoxazolo[2,3-a]imidazol-3-carboxylic acid ethyl ester (16a). Mixture of $\mathbf{1 a}(0.3 \mathrm{~g}, 2 \mathrm{mmol})$ and ethyl-2-methyleneethoxyacetoacetate $\mathbf{2 d}(0.38 \mathrm{~g}$, $2 \mathrm{mmol})$ in EtOH ( $2 \mathrm{ml})$ was kept $12 \mathrm{~h}$ at room temperature. White solid was filtered off, washed with EtOH $(3 \times 1 \mathrm{ml})$ and recrystallized from EtOH. White solid, yield $63 \%, 0.36 \mathrm{~g}, \mathrm{mp} 121$ $123{ }^{\circ} \mathrm{C}$; IR $\left(v_{\max }, \mathrm{cm}^{-1}\right): 3405(\mathrm{OH}), 2980\left(\mathrm{CH}_{3}\right), 1716(\mathrm{C}=\mathrm{O}), 1207(\mathrm{C}-\mathrm{OEt}) .{ }^{1} \mathrm{H}$ NMR $\left(400.13 \mathrm{MHz}, \mathrm{CDCl}_{3}+\left(\mathrm{CD}_{3}\right)_{2} \mathrm{SO}\right): \delta 0.82-1.72\left(\mathrm{~m}, 8 \mathrm{H},\left(\mathrm{CH}_{2}\right)_{4}\right), 0.91(\mathrm{t}, J=7.08 \mathrm{~Hz} 3 \mathrm{H}$, $\left.\mathrm{OCH}_{2} \mathrm{CH}_{3}\right), 1.23(1.06)\left(\mathrm{s}, 3 \mathrm{H}, \mathrm{CH}_{3}\right), 2.92\left(\mathrm{~m}, 2 \mathrm{H},(\mathrm{CH})_{2}\right), 3.12(2.83)(\mathrm{d}, J=5.61(6.13) \mathrm{Hz}, 1 \mathrm{H}$, $\left.\mathrm{CHCO}_{2} \mathrm{Et}\right), 3.82\left(\mathrm{~m}, 2 \mathrm{H}, \mathrm{OCH}_{2} \mathrm{CH}_{3}\right), 4.98(4.71)(\mathrm{d}, J=5.61(6.13) \mathrm{Hz}, 1 \mathrm{H}, \mathrm{NCHN}), 5.26$ (br s, $1 \mathrm{H}, \mathrm{OH}), 7.43$ (br s, $1 \mathrm{H}, \mathrm{OH}) .{ }^{13} \mathrm{C} \mathrm{NMR}\left(100.63 \mathrm{MHz},\left(\mathrm{CDCl}_{3}+\left(\mathrm{CD}_{3}\right)_{2} \mathrm{SO}\right): \delta 13.8,23.3(4 \mathrm{C}\right.$, $\mathrm{CH}_{2}$ cyclohexane), 23.0 (22.3) $\left(\mathrm{OCH}_{2} \mathrm{CH}_{3}\right), 26.3$ (24.1) $\left(\mathrm{CH}_{3}\right), 60.3\left(\mathrm{OCH}_{2} \mathrm{CH}_{3}\right), 60.7(2 \mathrm{C}, \mathrm{CH}$ cyclohexane), 63.1 (65.5) $\left(\mathrm{CHCO}_{2} \mathrm{Et}\right), 102.6(105.8)(\mathrm{NCHN}), 118.4(118.5)(\mathrm{OCOH}), 168.2$ $(\mathrm{C}=\mathrm{O})$ (minor component in parenthesis). Anal. Calcd for $\mathrm{C}_{13} \mathrm{H}_{22} \mathrm{~N}_{2} \mathrm{O}_{5}$ (286.32): C, 54.53; $\mathrm{H}$, 7.74; N, 9.78; Found: C, 54.33; H, 7.79; N, 9.85 .

1,6-Dihydroxy-2,2,3,3,6-pentamethylhexahydroimidazo[1,2-b]isoxazole-7-carboxylic acid ethyl ester (16b) was obtained by the procedure described for 16a from $1 \mathbf{b}$ (150 mg, $1 \mathrm{mmol})$ and $2 d(190 \mathrm{mg}, 1 \mathrm{mmol})$. White solid, yield $86 \%, 250 \mathrm{mg}$, dec. $>90{ }^{\circ} \mathrm{C}$; IR $\left(v_{\max }, \mathrm{cm}^{-1}\right): 3143$ $(\mathrm{OH}), 2986\left(\mathrm{CH}_{3}\right), 1746(\mathrm{C}=\mathrm{O}), 1131$ (COEt). ${ }^{1} \mathrm{H}$ NMR (400.13 MHz, $\left(\mathrm{CDCl}_{3}\right): \delta$ 0.93, 0.98, 0.99 and $1.00\left(\mathrm{~s}, 12 \mathrm{H}, \mathrm{CH}_{3}\right), 1.13\left(\mathrm{t}, J=7.3 \mathrm{~Hz}, 3 \mathrm{H}, \mathrm{OCH}_{2} \mathrm{CH}_{3}\right), 1.45(1.29)\left(\mathrm{s}, 3 \mathrm{H}, \mathrm{CH}_{3}\right), 3.05$ (3.04) $\left(\mathrm{d}, J=6.76 \mathrm{~Hz}(J=6.8 \mathrm{~Hz}) 1 \mathrm{H}, C \mathrm{HCO}_{2} \mathrm{Et}\right), 4.89(4.88)(J=6.76 \mathrm{~Hz}(J=6.78 \mathrm{~Hz}) 1 \mathrm{H}$, $\mathrm{NCHN}$ ), $4.05\left(\mathrm{~m}, 2 \mathrm{H}, \mathrm{OCH}_{2} \mathrm{CH}_{3}\right), 4.71$ (4.23) (br s, 1H, OH); 6.64 (7.58) (br s, 1H, OH) (minor component in parenthesis). Anal. Calcd for $\mathrm{C}_{13} \mathrm{H}_{24} \mathrm{~N}_{2} \mathrm{O}_{5}$ (288.34): C, 54.15; H, 8.39; N, 9.72; Found: C, 53.85; H, 8.19; N, 9.90.

Oxidation of (16b) into NNR (18b) and (19Na) isolation. To solution of $\mathbf{1 6 b}(0.57 \mathrm{~g}, 2 \mathrm{mmol})$ in $\mathrm{MeOH}(10 \mathrm{ml}) \mathrm{PbO}_{2}(40 \mathrm{mmol})$ was added and mixture was vigorously stirred at r.t. for 30 min. Red-violet solution was filtered off from oxidant and treated with equivalent amount of $\mathrm{MeONa}(0.4 \mathrm{ml} ; 4.95 \mathrm{M}$ in $\mathrm{MeOH})$. Deep violet solution was formed immediately and solvent was removed under reduced pressure. Dark violet residue was dissolved in minimum of acetone and filtered off. Acetone was removed under reduced pressure and residue was treated with hexane and filtered off. Dark violet powder, yield 32\%, $202 \mathrm{mg}$, dec $>100{ }^{\circ} \mathrm{C}$; UV (MeOH, $\left.\lambda_{\max }, \mathrm{nm}(\lg \varepsilon)\right): 262$ (4.17), 314 (4.12), 573 (3.10). Anal. Calcd for $\mathrm{C}_{13} \mathrm{H}_{20} \mathrm{~N}_{2} \mathrm{NaO}_{5} \cdot 2 \mathrm{H}_{2} \mathrm{O}$ (343.33): C, 45.48; H, 7.05; N, 8.16. Found: C, 45.47; H, 6.71; N, 7.79. The same protocol was used to obtain 19Li and 19K.

3-Oxotetrahydrothiophene-2-carbaldehyde-1,1-dioxide (2e). Mixture of 3oxotetrahydrothiophene-1,1-dioxide 20 (4.15 g, $31.0 \mathrm{mmol})$, triethyl orthoformate (11.7 g, $80.0 \mathrm{mmol})$ and $\mathrm{Ac}_{2} \mathrm{O}(16.6 \mathrm{~g}, 163.0 \mathrm{mmol})$ was refluxed for $1 \mathrm{~h}$. After cooling to $20^{\circ} \mathrm{C}$ needle precipitate was immediately formed. Residue was filtered off, washed carefully with $\mathrm{Et}_{2} \mathrm{O}$ $(3 \times 20 \mathrm{ml})$ and recrystallized from $\mathrm{AcOH}$. Pale pink crystals, yield 83\%, $4.14 \mathrm{~g}, \mathrm{mp} 175-179{ }^{\circ} \mathrm{C}$; IR $\left(v_{\max }, \mathrm{cm}^{-1}\right): 2700-2300(-\mathrm{OH}), 1573(\mathrm{C}=\mathrm{C}-\mathrm{C}=\mathrm{O}) .{ }^{1} \mathrm{H}$ NMR $\left(200.13 \mathrm{MHz},\left(\mathrm{CD}_{3}\right)_{2} \mathrm{SO}\right): \delta 2.87$ (t, $J=7.5 \mathrm{~Hz}, 2 \mathrm{H}, C \mathrm{H}_{2} \mathrm{COH}$ ), 3.41 (t, $J=7.5 \mathrm{~Hz}, 2 \mathrm{H}, C_{2} \mathrm{SO}_{2}$ ), 6.18 (br s, $1 \mathrm{H}, \mathrm{OH}$ ), 9.18 (s, $1 \mathrm{H}$, 
CHO). Anal. Calcd for $\mathrm{C}_{5} \mathrm{H}_{6} \mathrm{O}_{4} \mathrm{~S}$ (162.16): C, 37.03\%; H, 3.73\%; S, 19.77\% $\mathrm{C}_{5} \mathrm{H}_{6} \mathrm{O}_{4} \mathrm{~S}$; Found: C, $36.37 \%$; H, 3.71\%; S, $19.55 \%$.

cis-1,2-Bis(hydroxy-(2-methylene-1,1-dioxotetrahydrothiophene-3-on)amino)cyclohexane (22). To suspension of $1 \mathbf{a}(0.146 \mathrm{~g}, 1 \mathrm{mmol})$ in $\mathrm{EtOH}(1 \mathrm{ml}) \mathrm{HCl}_{\text {(conc.) }}$ was added till $\mathrm{pH}=2-3$. Then aldehyde $2 \mathrm{e}(0.170 \mathrm{~g}, 1 \mathrm{mmol})$ was added by small portions and obtained solution was kept for $24 \mathrm{~h}$ at room temperature. Deposited crystals were separated, washed with EtOH $(2 \times 1 \mathrm{ml})$ and dried. Dark brown crystals, yield 50\%, $0.110 \mathrm{~g}, \mathrm{mp} 253-257^{\circ} \mathrm{C}$; IR $\left(v_{\max }, \mathrm{cm}^{-1}\right): 1606(\mathrm{C}=\mathrm{C}-$ $\mathrm{C}=\mathrm{O}(\mathrm{N})), 1286,1104\left(\mathrm{SO}_{2}\right) .{ }^{1} \mathrm{H}$ NMR $\left(400.14 \mathrm{MHz},\left(\mathrm{CD}_{3}\right)_{2} \mathrm{SO}\right): \delta 1.46-2.26\left(3 \mathrm{~m}, 8 \mathrm{H},\left(\mathrm{CH}_{2}\right)_{4}\right)$, 2.82 (s, 4H, $\left.\mathrm{CH}_{2} \mathrm{COH}\right), 3.41$ (s, 4H, $\left.\mathrm{CH}_{2} \mathrm{SO}_{2}\right), 4.07\left(\mathrm{~s}, 2 \mathrm{H},(\mathrm{CH})_{2}\right), 7.79(\mathrm{~s}, 1 \mathrm{H}, \mathrm{N}=\mathrm{CH}), 15.7$ (br s, 2H, OH). ${ }^{13} \mathrm{C}$ NMR (400.13 MHz $\left.\left(\mathrm{CD}_{3}\right)_{2} \mathrm{SO}\right): \delta 21.8,26.9\left(8 \mathrm{C}, \mathrm{CH}_{2}\right.$ cyclohexane), $30.6(2 \mathrm{C}$, $\left.\mathrm{CH}_{2} \mathrm{COH}\right), 50.5$ (2C, $\left.\mathrm{CH}_{2} \mathrm{SO}_{2}\right), 66.3$ (4C, $\mathrm{CH}$ cyclohexane), $104.3\left(\mathrm{CSO}_{2}\right), 138.2$ (CHNO), 186.6 (=COH). Anal. Calcd for $\mathrm{C}_{16} \mathrm{H}_{22} \mathrm{~N}_{2} \mathrm{O}_{8} \mathrm{~S}_{2}$ (433.48): C, 44.33; H, 4.88; N, 6.46; S, 14.79 Found: C, 43.68; H, 5.09; N, 6.46; S, 14.62 .

\section{X-Ray structure determinations}

XRD data (Table 1) for compound 9a were obtained on a Bruker P4 diffractometer with graphite-monochromated Mo- $K \alpha$ radiation. The structure was solved by direct methods using the SHELXS-97 program $^{23}$ and refined by the least-squares method in the full-matrix anisotropic (isotropic for all $\mathrm{H}$ atoms) approximation using the SHELXL-97 program. ${ }^{23}$ Absorption correction was applied by integration method (transmission 0.9691-0.9005). The hydrogen positions were taken from difference Fourier map and those which bonded to oxygens and nitrogens were refined with the distance restraints $\mathrm{O}-\mathrm{H} 0.85 \mathrm{~N}-\mathrm{H} 0.92 \AA$. The asymmetric part of the unit cell includes two molecules of water. The obtained crystal structure was analyzed for short contacts between non-bonded atoms and hydrogen bonding (Table 1) using the PLATON program. ${ }^{24}$ CCDC-734585 contains the supplementary crystallographic data for this paper. These data can be obtained free of charge from The Cambridge Crystallographic Data Center via www.ccdc.cam.ac.uk/data_request/cif.

Crystallographic data for comp 9a: $\mathrm{C}_{12} \mathrm{H}_{23} \mathrm{~N}_{2} \mathrm{O}_{7} \mathrm{Cl}, M=342.76 \mathrm{~g} / \mathrm{mol}$, monoclinic, $P 2_{1} / c$, $a=8.1462(12), b=23.630(3), c=8.7648(10) \AA, \beta=95.272(9)^{\circ}, \mathrm{V}=1680.1(4) \AA 3, \mathrm{Z}=4$, $D_{\text {calcd }}=1.355 \mathrm{~g} \cdot \mathrm{cm}^{-3}, \mu(\mathrm{Mo}-\mathrm{K} \alpha)=0.261 \mathrm{~mm}^{-1}, \mathrm{~F}(000)=728,\left(\theta 2.49-26.00^{\circ}\right.$, completeness $100 \%), \mathrm{T} 296(2) \mathrm{K}$, colorless alongated plate, $(0.96 \times 0.40 \times 0.12) \mathrm{mm}^{3}, 3526$ measured reflections in index range $0<=h<=10,-29<=k<=0,-10<=l<=11,3290$ independent $\left(R_{\text {int }}=\right.$ 0.0309), 13 restraints, 290 parameters, 2558 observed [I> $2 \sigma(I)], R_{1}=0.0438, w R^{2}=0.1192$ (all data), GOOF 1.012, largest diff. peak and hole 0.241 and -0.212 e. $\mathrm{A}^{-3}$. 


\section{References}

1. (a) Mazhukin, D. G.; Volodarskii, L. B.; Tikhonova, L. A.; Tikhonov, A. Y. Mendeleev Commun. 1992, 2, 29. (b) Utepbergenov, D. I.; Khramtsov, V. V.; Vlassenko, L. P.; Markel, A. L.; Mazhukin, D. G.; Tikhonov, A. Y.; Volodarsky, L. B. Biochem. Biophys. Res. Commun. 1995, 214, 1023.

2. Mazhukin, D. G.; Tikhonov, A. Y.; Reznikov, V. A.; Volodarsky, L. B. Mendeleev Commun. 2000, 10, 69.

3. (a) Mazhukin, D. G.; Tikhonov, A. Y.; Volodarskii, L. B.; Konovalova, E. P. Chem. Heterocycl. Compd. 1993, 29, 437; Chem. Abstr. 1994, 120, 134422. (b) Mazhukin, D. G.; Tikhonov, A. Y.; Volodarsky, L. B., Evlampieva, N. P.; Vetchinov, V. P.; Mamatyuk, V. I. Liebigs Ann. Chem. 1994, 983.

4. Butakov, V. V.; Khlestkin, V. K.; Mazhukin, D. G. Mendeleev Commun. 2005, 15, 162.

5. (a) Severina, I. A.; Ryaposova, I. K.; Volodarsky, L. B.; Mazhukin, D. G.; Tikhonov, A. Y.; Schwartz, G. Y.; Granik, V. G.; Grigor'ev, D. A.; Grigor'ev, N. B. Biochem. Mol. Biol. Int. 1993, 30, 357. (b) Schwartz, G. Y.; Grigor'ev, I. B.; Severina, I. A.; Ryaposova, I. K.; Lapitskaya, A. S.; Volodarsky, L. B.; Tikhonov, A. Y.; Kurbnikova, I. F.; Mazhukin, D. G.; Granik, V. G. Khim. Pharm. Zh. (Russ.) 1994, 28, 4, 38; Chem. Abstr. 1994, 121, 170187.

6. Tikhonov, A. Y.; Mazhukin, D. G.; Grigor'eva, L. N.; Khlestkin, V. K.; Voinova, N. N.; Syropyatov, B. Y.; Shirinkina, S. S.; Volodarsky, L. B. Arch. Pharm. - Pharm Med. Chem. 1999, 332, 305.

7. (a) Volodarsky, L. B.; Reznikov, V. A.; Ovcharenko, V. I. Synthetic chemistry of stable nitroxides; CRC Press Inc: Boca Raton, Florida, 1994, p 221. (b) Tretyakov, E. V.; Ovcharenko V. I. Russ. Chem. Rev. 2009, 78, 971.

8. (a) Zhang, W.; Basak, A.; Kosugi, Y.; Hoshino, Y.; Yamamoto, H. Angew. Chem. Int. Ed. 2005, 44, 4389. (b) Zhang, W.; Yamamoto, H. J. Am. Chem. Soc. 2007, 129, 286.

9. Basak, A.; Barlan, A. U.; Yamamoto, H. Tetrahedron: Asymmetry 2006, 17, 508.

10. Oh, Y. S.; Kotani, S.; Sugiura, M.; Nakajima, M. Tetrahedron: Asymmetry 2010, 21, 1833.

11. Barlan, A. U.; Zhang, W.; Yamamoto, H. Tetrahedron 2007, 63, 6075.

12. (a) Nishiwaki, N.; Takada, Y.; Inoue, Y.; Tohda, Y.; Ariga, M. J. Heterocyclic Chem. 1995, 32, 473. (b) Nishiwaki, N.; Nogami, T.; Kawamura, T.; Asaka, N.; Tohda, Y.; Ariga, M. J. Org. Chem. 1999, 64, 6476. (c) Matsushima, K.; Tamura, M.; Hori, K.; Tohda, Y.; Nishiwaki, N.; Ariga, M. Nippon Kagakkai Koen Yokoshu 2002, 81, 1022. (d) Nishiwaki, N.; Ogihara, T.; Takami, T.; Tamura, M.; Ariga, M. J. Org. Chem. 2004, 69, 8382. (e) Nishiwaki, N.; Ariga, M. In Bioactive Heterocycles; Eguchi, S.; Gupta, R. R. Eds.; Springer: Berlin, Heidelberg, 2007; Vol. 2, pp. 43-72. (f) Nakaike, Y.; Hayashi, D.; Nishiwaki, N.; Tobe, Y.; Ariga, M. Org. Biomol. Chem. 2009, 7, 325.

13. Reznikov, V. A.; Roshchupkina, G. I.; Mazhukin, D. G.; Petrov, P. A.; Popov, S. A.; Fokin, S. V.; Romanenko, G. V.; Rybalova, T. V.; Gatilov, Y. V.; Shvedenkov, Y. G.; Irtegova, I. G.; Shundrin, L. A.; Ovcharenko, V. I. Eur. J. Org. Chem. 2004, 749. 
14. Grassi, G.; Bruno, G.; Risitano, F.; Foti, F.; Caruso, F.; Nicolo, F. Eur. J. Org. Chem. 2001, 4671.

15. Wang, H.-T.; Wang, X.-J.; Huang, Z.-T. Chem. Ber. 1990, 123, 2141.

16. Nair, M. D.; Rajappa, S.; Desai, J. A. Indian J. Chem., Sect. B 1982, 21, 1; Chem. Abstr. 1982, 96, 217794.

17. Boocock, D. G. B.; Darcy, R.; Ullman E. F. J. Am. Chem. Soc. 1968, 21, 5945.

18. (a) Claisen, L. Ber. Deutsch. Chem. Gesell. 1893, 26, 2729. (b) Jones, R. G. J. Am. Chem. Soc. 1952, 74, 4889.

19. Belletire, J. L.; Spletzer, E. G. Synthetic Commun. 1983, 13, 269.

20. Mazhukin, D. G.; Tikhonov, A .Y.; Volodarskii, L. B.; Konovalova, E. P.; Tikhonova, L. A.; Bagryanskaya, I. Y.; Gatilov, Y. V. Russ. Chem. Bull. 1993, 42, 851 (Engl. Transl.).

21. (a) Ovcharenko, V. I.; Fokin, S. V.; Korobkov, I. V.; Rey P. Russ. Chem. Bull. 1999, 48, 1519 (Engl. Transl.). (b) Hirel, C.; Vostrikova, K. E.; Pecaut, J.; Ovcharenko, V. I.; Rey. P. Chem. Eur. J. 2001, 7, 2007.

22. (a) Wang, J.-H.; Shen, Y.-Q.; Yu, C.-X.; Si, J.-H. J. Chem. Soc., Perkin Trans. 1. 2000, 1455. (b) Jones, R. G. J. Am. Chem. Soc. 1951, 73, 3684.

23. Sheldrick, G. M. SHELX-97 - Programs for Crystal Structure Analysis, Release 97-2, University of Goettingen, Goettingen, Germany.

24. (a) Spek, A. L. PLATON, A Multipurpose Crystallographic Tool, Version 10M, Utrecht University, Utrecht, The Netherlands, 2003. (b) Spek, A. L. J. Appl. Crystallogr. 2003, 36, 7. 